\title{
The Informational Content Of Voluntary Embedded Value (EV) Financial Disclosures By Canadian Life Insurance Companies During The Recent Period Of Market Turmoil
}

\author{
Jacques Préfontaine, Ph.D., Université de Sherbrooke, Canada \\ Jean Desrochers, Ph.D., Université de Sherbrooke, Canada \\ Lise Godbout, M.Sc., Université de Sherbrooke, Canada
}

\begin{abstract}
The informational content and relevance to external stakeholders of voluntary financial disclosures by commercial banks is now becoming more widely recognized. For instance, banks' voluntary disclosures of liquidity, interest rate and market risk metrics have been found to be closely associated with market value of equity and credit ratings. So far, there has been very scarce published research on investigating the informational content and relevance to external stakeholders of voluntary financial disclosures by life insurance companies during the recent period of market turmoil. In order to improve upon this situation, this paper updates previous findings and reports on the informational content of voluntary embedded value (EV) financial disclosures by Canadian life insurance companies during the 2000-2010 time period. As opposed to traditional statutory balance sheet and earnings' reporting, EV voluntary disclosure attempts to estimate the present value of future earnings generated by a life insurer's current book of various insurance businesses. The preliminary results presented in this study indicate that recent EV voluntary financial disclosures failed to communicate intrinsic informational content and to provide value relevance to external stakeholders in the sense that they were not found to be closely associated with life insurers' market value of equity and credit ratings during the recent 20072010 period of market turmoil.
\end{abstract}

Keywords: embedded value; financial disclosure; informational content; life insurance; value relevance

\section{INTRODUCTION}

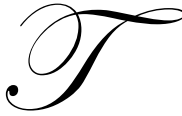

his paper examines the informational content and the usefulness of life insurers' embedded value (EV) public financial disclosures. This theme is of interest since the factors that influence the market value (MV) of life insurers are complex, and they strongly interact with other intervening factors from related value metrics like book value (BV). These characteristics have made it more difficult for financial services industry regulators and private sector ERM experts to recommend a practical and well defined framework for the management and subsequent public disclosure of life insurers' embedded value (EV) financial information. Lopez (2003), and more recently, Kwan (2006), explained the ongoing international efforts to improve regulation and supervision of financial institutions to reflect advances in financial risk management techniques. Their analysis supports the view that improved public disclosures regarding conditions, operations, performance, as well as value related and risk management information lead to increased transparency and should foster more effective market discipline. 
The evolution of financial disclosure in the banking, insurance and securities sectors has been described in a study published by the Joint Forum (2004) of the Basel Committee on Banking Supervision (BCBS). The BCBS, the International Association of Insurance Supervisors (IAIS) and the International Organization of Securities Commissions (IOSCO) established, through the Joint Forum, a Working Group on enhanced disclosure. This paper will also examine the results of a recent study presented by Horton (2007) which examined the value relevance of realistic reporting by UK life insurers. The results presented in this study are based on a statistical analysis of the EV voluntary financial disclosures presented from 2000 to 2009 in their annual reports by a group of Canadian life insurance companies.

The rest of the paper is structured as follows: Agency theory is presented in section two. Section two also defines and examines the key insurance risk management factors. Important distinctions are made between a life insurance company's common shareholders' equity metrics: book value (BV), embedded value (EV), and market value (MV). The third section describes the research methods, the sample of Canadian life insurance companies, and formulates hypotheses on the extent and quality of life insurers' qualitative and quantitative disclosures of embedded value information. Section four presents and discusses the study's empirical results. Finally, the conclusions, limits of the study and suggestions for further research are drawn in the fifth section.

\section{RISK MANAGEMENT INFORMATION AND EMBEDDED VALUE (EV) FINANCIAL DISCLOSURES}

Gardner et al. (2005) discuss how Agency Theory, a positive view of managerial decision making helps explain how risk management decisions are actually made by financial institution managers rather than prescribing how they should be made. In their view, Agency Theory implies that financial institutions' managers set financial risk management objectives and determine estimates of potential losses that could result from their business activities. While owners and their delegated monitors (regulators, credit rating agencies, financial analysts...) protect their interests by setting appropriate risk management constraints and financial disclosure standards and requirements.

Recently, several authors have examined if improved financial risk information disclosures lead to increased transparency and more effective market discipline. In his study of VaR disclosures, Jorion (2002) found that VaR numbers in quarterly and annual reports from 1995 to 2000, of eight publicly traded U.S. commercial banks provided reasonable predictions of the subsequent variability of their trading revenues.

Hirtle (2003) found that the market risk minimum capital adequacy requirement measure reported by commercial banks is informative of the level of market risk associated with the trading activities of U.S. commercial banks. In still another study, Liu, Ryan and Tan (2004) reported that the VaR measure also had an informational content about the systematic risk and the total risk encountered by U.S. commercial banks. Préfontaine et al. (2006a) recently presented comparable results on Canadian banks' VaR disclosures. In another area of financial risk management; that is, non-trading interest rate risk management, Lopez (2004) documents the usefulness of financial institutions' disclosures. The results of several empirical tests support the view that the disclosure of non-trading interest rate risk metrics like Earnings-at-Risk and Economic Value of Equity-at-Risk represents useful information to market participants. This last conclusion applies to U.S. banks according to Lopez (2004) and to large U.S. and Canadian commercial banks studied by Préfontaine et al. (2006b).

Some of the earlier work by the BCBS discussed the role of information in effective market discipline and effective supervision. It established that financial institution transparency would be enhanced by public disclosure and supervisory information that promote safety and soundness. The BCBS (2000) study outlined a set of sound practices for managing liquidity in banking organisations. This updated guidance was organised around a set of fourteen principles falling into the following eight key liquidity management areas: developing a structure for managing liquidity, measuring and monitoring net funding requirements, managing market access, contingency planning, foreign currency liquidity management, internal controls for liquidity risk management, role of public disclosure improving liquidity and role of supervisors. 
During the same time period, the Working Group (Joint Forum) formulated and recommended disclosure practices regarding financial risks. The universe of financial intermediaries to which the recommendations were intended consists of banks, securities firms, insurance companies and hedge funds. The Working Group believed that these financial intermediaries, regulated and unregulated, should periodically disclose both qualitative and quantitative financial information, when material, in a way that in the firm's judgement most meaningfully expresses its exposures to financial risks. The Working Group (2001) specifically made the recommendations to disclose: "substantive qualitative discussion of funding liquidity risk that includes some quantitative information supporting the discussion." The Working Group also recommended that disclosures be made which cover two important aspects of liquidity management: funding liquidity risk and market liquidity risk.

More recently, the BCBS (2003) published a report providing an overview of the disclosure practices of a sample of internationally active banks. The survey focussed on the year 2001 annual reports of 54 banks headquartered in the Committee's member countries. The survey included 104 questions addressing quantitative and qualitative disclosures in twelve different categories. In general terms, the survey revealed that many banks have continued to expand the extent of their disclosures. Overall, in book year 2001, banks disclosed $63 \%$ of the items, 104 questions, included in the survey, up from 59\% in 2000 and 57\% in 1999. In the main findings of its study, the BCBS (2003) noted: "The most noteworthy improvement is the increase in the disclosure of information on other risks (operational and legal risks, liquidity risk and interest rate risk in the banking book)". It added that this information has now become as commonly disclosed as the basic information on market risk or credit risk. It also reported that: " $85 \%$ of the banks disclosed quantitative and qualitative information and strategies for managing liquidity risk in their year 2001 annual reports, up from 78\% in 2000 and 63\% in 1999". We believe that the BCBS findings reported above on liquidity risk management financial disclosures can only be considered to be preliminary. This belief is based on the fact that only one out of a possible 104 questions in the three successive disclosure surveys, 1999-2000-2001, directly addressed the liquidity risk management category. Furthermore, the survey results in this case only represent the number of affirmative answers to the presence of "disclosed quantitative and qualitative information and strategies for managing liquidity risk". For instance, the number of affirmative answers to the single liquidity disclosure question was 46 (banks) out of a possible 54 banks in 2001; thus, a disclosure rate of $85 \%$.

To assess the extent to which its previous recommendations were adopted, the BCBS and its Joint Forum (2004) reviewed the 2002 annual reports of 66 financial institutions from 12 countries in the banking, insurance and securities sectors. In addition to surveying public disclosures, the Working Group held meetings with representatives from the investment community, credit rating agencies and financial firms in order to gain their views in the degree of adoption of its previous recommendations and ways to improve public disclosures. The Working Group found that disclosure related to funding liquidity risk is a very complex issue, due primarily to the difficulty of quantifying the level of the risk in a way that is meaningful for disclosure purposes as well as the firm's sensitivity that such disclosures must be carefully considered in order not to provide misleading and potentially damaging information. Of more importance to the focus of this study, was the fact that with few exceptions, most of the firms surveyed included a discussion of funding liquidity in their annual reports. However, the extent of quantitative information supporting the discussion is generally weak. Members of the Joint Forum stated that improvement in quantitative disclosures with regard to funding liquidity risk was clearly needed. Although they believed that the way to do this effectively remained a challenge. The Working Group also reviewed disclosure areas requiring further investigation and development from a conceptual point of view. The Working Group agreed that further work in three of these areas should be pursued: disclosures of risk concentrations, potential future exposure and funding liquidity risk. It felt that the goal should be to find a way for financial firms to disclose in a meaningful way information they already possess as part as their internal risk management processes. The last paper we review was presented by the BCBS and its Joint Forum (2006), it presented the results of a review of funding liquidity risk management practices ${ }^{1}$ at conglomerates engaged in banking, securities and insurance activities. The review focussed on 40 large, complex

\footnotetext{
1 "Funding liquidity risk is the risk that the firm will not be able to efficiently meet both expected and unexpected current and future cash flow and collateral needs without affecting either daily operations or the financial condition of the firm. It differs from market liquidity risk, which is the risk that a firm cannot easily offset or eliminate a position without significantly affecting the market price because of inadequate market depth or market disruption." As the Working Group observes, in many cases, the same factors may trigger both types of liquidity risk.
} 
financial groups with operations spanning national borders, financial sectors and currencies. The majority of the financial institutions represented in the review were involved in at least two of the banking, securities, or insurance sectors. All observations were based on information and opinions provided by the firms through written responses to a survey, interviews and presentations to the Working Group. The review was designed to address five key questions:

- How large, complex banking, securities and insurance groups manage liquidity risks across jurisdictions, sectors, and subsidiary units, particularly in times of stress;

- The impact of regulatory and supervisory approaches on liquidity risk management practices and structures;

- The nature of the products and activities that give rise to significant demands for liquidity;

- $\quad$ Assumptions that firms make regarding available sources of liquidity; and

- $\quad$ The scale of liquidity shocks that firms are prepared to address.

The Working Group reviewed the extent to which financial groups integrate liquidity risk management across sectors. Firms in each of the three sectors, banking and insurance as well as securities, monitor and manage liquidity risk primarily through the use of risk limits, monitoring systems, and scenario analyses that are incorporated into contingency funding plans (CFPs). However, given differences in business lines and funding mix, liquidity risk management is mostly separated in financial groups that contain firms operating in multiple sectors.

As noted by Desrochers and Préfontaine (2008), previous empirical work has demonstrated the importance and complexity of financial institutions' liquidity risk financial disclosure. There appears to be a wide consensus that further work in the area of managing and reporting liquidity risk should be pursued. In doing so, the two following aspects of liquidity risk have to be considered: funding liquidity risk and market liquidity risk. Further empirical work benefits from updated guidance organized around a set of principles falling into several liquidity management areas. Financial institutions' quarterly and annual reports represent important and low-cost sources of financial disclosure to all of their stakeholders. Liquidity risk financial information should embody substantive qualitative disclosures that include some quantitative information supplementing the discussion.

More closely related to the focus of this paper, Horton (2007) investigated the value relevance of 'realistic reporting' drawn from evidence of UK life insurers' embedded value financial disclosures. The author observes that: "the current accounting regime for UK life insurance companies is oriented towards delaying the recognition and distribution of profit, and still remains largely rooted in traditional requirements for statutory solvency reporting. Her paper tests empirically the value relevance of the alternative 'realistic reporting regime' of voluntary embedded value (EV) disclosures that has been generally adopted by leading UK and Continental European insurers. EVs have also been used internally (but not disclosed) by many US life insurers". Finally, the empirical results presented by the author were found to be consistent with value relevance and some implications for standard-setters were explored.

\section{EXAMINING THE EXTENT OF EMBEDDED VALUE FINANCIAL DISCLOSURE}

The objective of this paper is to examine the informational content and the usefulness of Canadian life insurers' embedded value public financial disclosure. The results of the analysis will be based on an in-depth content analysis of the annual reports from 2000 to 2009 published by four of Canada's largest publicly listed life insurance companies. A statistical analysis will also be carried out to examine the relationship, if any, between "ex ante" metrics like book value of equity (BV), embedded value of equity (EV), and "ex post" subsequent market value of equity (MV).

\subsection{The results of the analysis will attempt to answer the following five research questions:}

\section{Question 1:}

- $\quad$ Does the extent of embedded value public financial disclosure differ across the four Canadian life insurers composing the study sample? 


\section{Question 2:}

- Does the frequency (annual or quarterly) of embedded value public financial disclosure differ across the four Canadian life insurers composing the study sample?

\section{Question 3:}

- Does the extent of embedded value public financial disclosure differ across the credit rating of each of the four Canadian life insurers composing the study sample?

\section{Question 4:}

- What is the statistical relationship, if any, between contemporaneous metrics like book value of equity (BV), embedded value of equity (EV), and market value of equity (MV)?

\section{Question 5:}

- What is the statistical relationship, if any, between "ex ante" metrics like book value of equity (BV), embedded value of equity (EV), and "ex post" subsequent market value of equity (MV)?

\subsection{Canadian life insurers' sample description}

For those readers desiring to acquire more knowledge on the determination and analysis of a life insurer's embedded value metric, Table 1 in the text presents Manufacturers Life discussion and analysis of embedded value drawn from its 2009 Annual Report.

The study sample is composed of the four largest publicly listed Canadian life insurance companies. Table 2 in the text identifies the four companies by name, and provides the value of each company's total equity, total assets as well as its Standard \& Poor's long term subordinated debt credit rating.

\subsection{Key common shareholders' valuation metrics}

To examine the informational content of voluntary embedded value (EV) financial disclosures by Canadian life insurance companies, we used end-of-period (the $31^{\text {st }}$ of December) annual data on book value of common shareholders' equity (BV), market value of common shareholders' equity (MV), and embedded value of common shareholders' equity (EV). Unfortunately, Canadian life insurance companies did not disclose embedded value (EV) metrics quarterly; only annual disclosures were made. Naturally, this reduced the number of observations to about ten; that is, ten annual observations of EV for each company from year-end 2000 to year-end 2009.

In the text, Graph 1 plots an analysis by company of total equity values and common share value metrics from 2000 to 2009 . 
Graph 1

Analysis by Company of Total Equity and Per Common Share Value Metrics

INDUSTRIAL ALLIANCE GROUP (IAG)
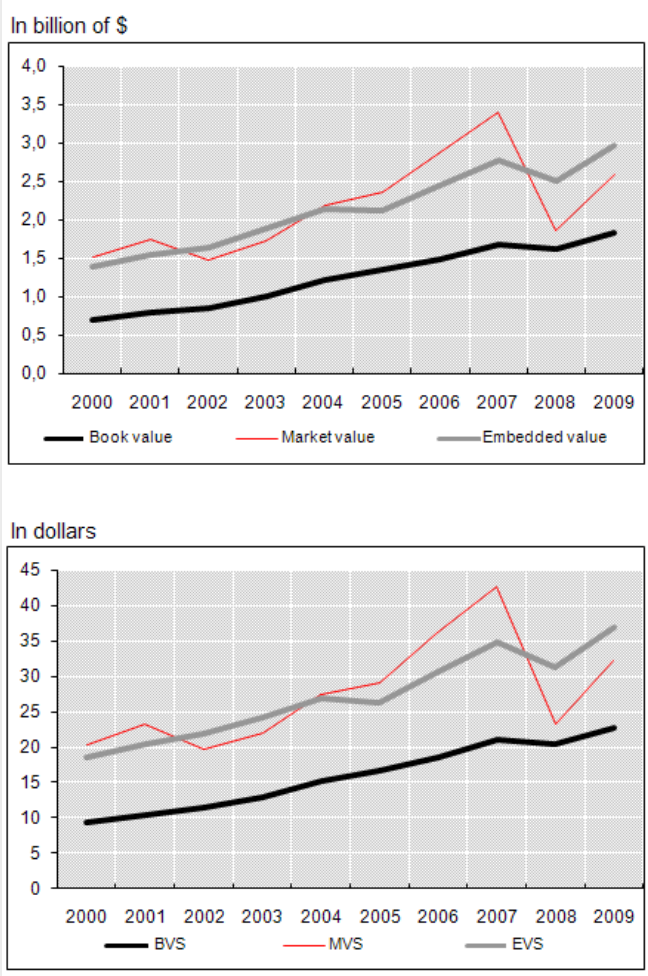

MANULIFE FINANCIAL (MFC)
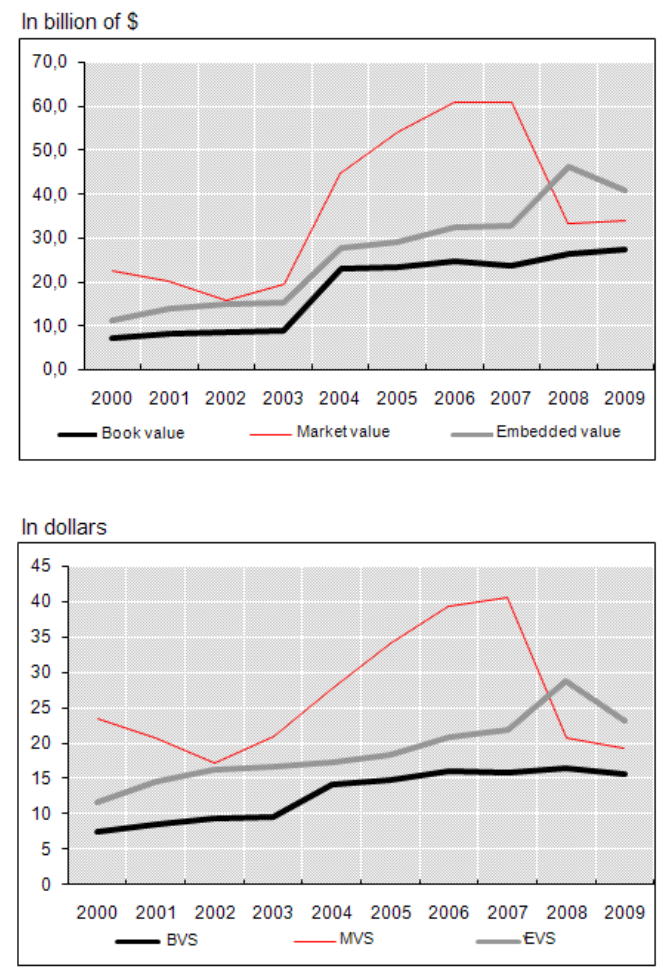

SUN LIFE FINANCIAL (SLF)
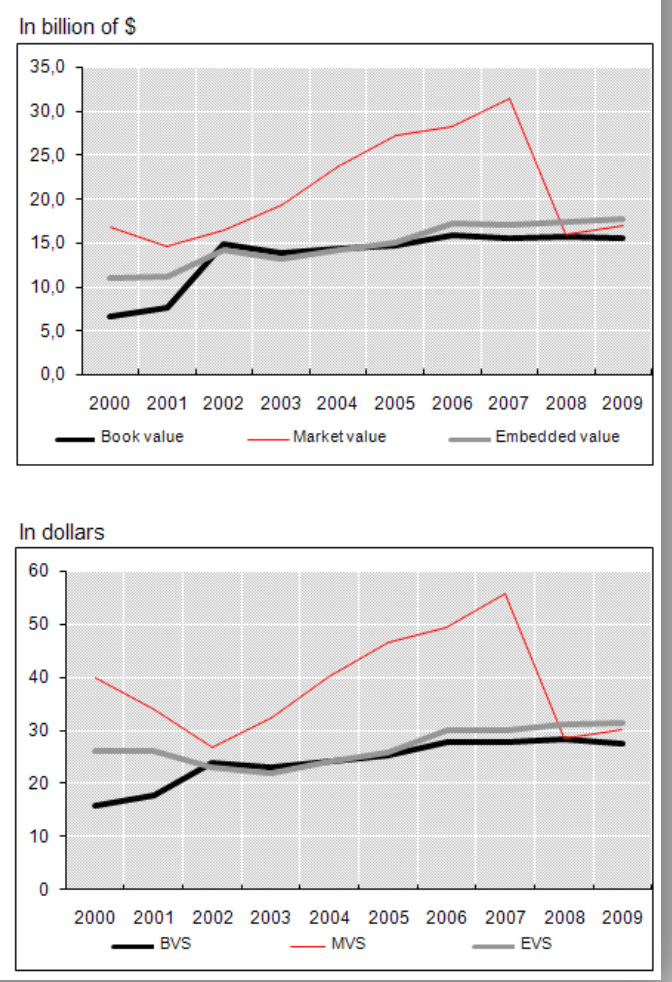
Table 1

Manufacturers Life Discussion and Analysis of Embedded Value

\section{Embedded Value}

Embedded value is a measure of the shareholder value embedded in the current balance sheet of the Company, excluding any value associated with future new business. The change in embedded value between reporting periods is used by Manulife Financial's management as a measure of the value created by the year's operations. Embedded value is a non-GAAP measure.

Manulife Financial's embedded value is defined as adjusted Canadian GAAP shareholders' equity plus the value of in-force business. The adjusted Canadian GAAP shareholders' equity is the fiscal year end Canadian GAAP shareholders' equity adjusted for goodwill and intangibles, fair value of surplus assets, third party debt and pension liabilities. The value of in-force business is the present value of expected future Canadian GAAP earnings on in-force business less the present value cost of holding capital required to support the in-force business. Required capital uses the Canadian MCCSR required capital framework.

As at December 31, 2009, Manulife's embedded value was $\$ 40.8$ billion, a decrease of $\$ 5.4$ billion over December 31, 2008. Positive growth in Embedded Value from operational items, including new business and experience variances, was offset by the impact of currency movements (higher Canadian dollar reducing value of non Canadian business) and higher discount rates (due to movement in market interest rates).

\section{Embedded Value}

For the years ended December 31,

(Canadian $\mathbf{S}$ in millions unless otherwise stated)

Embedded value as at January 1

Interest on embedded value

New business

Experience variances and changes in actuarial assumptions

Embedded value before discount rate, currency and capital movements

Discount rate changes

Surplus yield changes

Currency

Common shareholder dividends

Other capital movements (1)

Embedded value as at December 31

Embedded value per share

Annual growth rate in embedded value (before impact of discount rate, currency, dividends and capital changes)

20092008

$\$ 46,183 \$ 32,799$

$3,038 \quad 2,560$

$2,453 \quad 2,260$

$1,022 \quad(4,583)$

$\$ 52,696 \$ \$ 33,036$

$(6,333) \quad 6,493$

(879)

$(\mathbf{5}, \mathbf{9 1 0}) \quad 6,303$

$(1,264) \quad(1,494)$

$\mathbf{2 , 4 8 0} \quad 1,845$

$\$ 40,790 \$ 46,183$

$\$ 23.20 \$ 28.68$

(1) Includes share issues, repurchases and option exercises.

The embedded value can be reconciled to the financial statements as follows:

As at December 31,

(Canadian $\mathbf{S}$ in millions)

Shareholders' equity on balance sheet (excludes preferred shares) $\mathbf{\$ 2 7 , 4 0 5} \$ 26,755$

Fair value adjustments

Goodwill and (post-tax) intangibles

$(1,143) \quad(611)$

$(\mathbf{8 , 4 2 5 )} \quad(9,142)$

Value of shareholders' net equity

\$ $17,837 \$ 17,002$

Pre-tax value of expected profit embedded in CGAAP policy liabilities (reported actuarial provision for adverse deviation -

PfAD)(1)

Adjustments:

Value of additional policy margins not captured in actuarial PfAD

$\$ 42,088 \$ \$ 44,821$

Taxes

Converting discount rates from valuation rates to higher cost of capital adjusted discount rates

Cost of locked-in capital

$\mathbf{5 , 0 6 7} \quad 3,672$

$(12,611) \quad(13,706)$

$(6,748) \quad(2,760)$

$(4,843) \quad(2,846)$

Value of in-force business

\$ 22,953 \$29,181

Embedded value

$\$ \mathbf{4 0 , 7 9 0} \$ 46,183$

(1) The reported actuarial PfAD includes non-capitalized segregated fund margins. 
Table 1

Manufacturers Life Discussion and Analysis of Embedded Value (continued)

The principal economic assumptions used in the embedded value calculations in 2009 were as follows:

\begin{tabular}{|c|c|c|c|c|}
\hline & Canada & U.S. & Hong Kong & Japan \\
\hline MCCSR ratio & $150 \%$ & $150 \%$ & $150 \%$ & $150 \%$ \\
\hline Discount rate & $7.75 \%$ & $8.00 \%$ & $8.50 \%$ & $6.50 \%$ \\
\hline Risk premium & $4.0 \%$ & $4.0 \%$ & $5.0 \%$ & $5.0 \%$ \\
\hline Inflation & $2.0 \%$ & $2.0 \%$ & $2.0 \%$ & $0.0 \%$ \\
\hline Income tax rate & $26 \%$ & $35 \%$ & $16.5 \%$ & $36 \%$ \\
\hline Foreign exchange rate & $\mathrm{n} / \mathrm{a}$ & 1.0466 & 0.1350 & 0.0112 \\
\hline
\end{tabular}

Discount rates have been derived from government bond rates in the respective countries, plus risk premiums varying from four per cent to five per cent. Higher discount rates were used in some Asian businesses. The weighted average discount rate is 8.0 per cent.

Surplus assets are projected forward at a pre-tax market return of 6.25 per cent for U.S. and Canadian dollar denominated assets, and 3.1 per cent for Yen denominated assets.

Consistent with normal practice, the foreign exchange rates and discount rates are updated each year to reflect prevailing market rates. Other principal assumptions are unchanged with the exception of the surplus yield. The key assumption changes are summarized below:

\begin{tabular}{|c|c|c|c|c|c|c|c|c|}
\hline Discount rates & 2009 & 2008 & Surplus yield & 2009 & 2008 & Exchange rates & 2009 & 2008 \\
\hline$\overline{C a n a d a}$ & $7.75 \%$ & $6.75 \%$ & Canada & $6.25 \%$ & $\overline{7.00 \%}$ & & & \\
\hline U.S. & $8.00 \%$ & $6.25 \%$ & U.S. & $6.25 \%$ & $7.00 \%$ & U.S. dollar & 1.0466 & 1.2246 \\
\hline Hong Kong & $8.50 \%$ & $7.00 \%$ & Hong Kong & $6.25 \%$ & $7.00 \%$ & Hong Kong dollar & 0.1350 & 0.1581 \\
\hline Japan & $6.50 \%$ & $6.25 \%$ & Japan & $3.10 \%$ & $3.10 \%$ & Japanese yen & 0.0112 & 0.0135 \\
\hline
\end{tabular}

Embedded value has been calculated using the financial position of the Company as at September 30,2009 projected to December 31, 2009, allowing for the actual change in key elements such as the market value of securities, new business contributions and in-force policy experience. The future stream of profits has been calculated on a Canadian GAAP basis in all countries using assumptions consistent with the best estimate assumptions used in the calculation of the actuarial liabilities. Future mortality improvements are recognized in best estimate assumptions on individual insurance business in North America. Assumed equity returns for projected fee income on segregated fund products are capped at the embedded value discount rates. The expected cost of segregated fund guarantees within the policy liabilities is determined using stochastic techniques. The Company's target equity/debt structure has been utilized, which assumes that 25 per cent of the capital is in the form of debt.

Source: Manufacturers Life, 2009 Annual Report, p. 156-157

Table 2

Financial Characteristics of Canadian Life Insurance Companies at Year-End 2009

\begin{tabular}{|c|c|c|c|}
\hline Company & $\begin{array}{l}\text { Total Equity } \\
\text { (M \$ CDN) }\end{array}$ & $\begin{array}{l}\text { Total Assets } \\
\text { (M \$ CDN) }\end{array}$ & $\begin{array}{l}\text { Standard \& Poor's } \\
\text { Credit Rating* }\end{array}$ \\
\hline $\begin{array}{l}\text { Great-West Lifeco } \\
\text { TSX: (GWO) }\end{array}$ & $\$ 13,003$ & $\$ 128,369$ & $\mathrm{AA}^{-}$ \\
\hline $\begin{array}{l}\text { Industrial Alliance } \\
\text { Group } \\
\text { TSX: (IAG) }\end{array}$ & 2,158 & 17,627 & A \\
\hline $\begin{array}{l}\text { SunLife Assurance } \\
\text { Company of Canada } \\
\text { NYSE: (SLF) }\end{array}$ & 17,414 & 120,082 & $\mathrm{~A}^{+}$ \\
\hline $\begin{array}{l}\text { The Manufacturers } \\
\text { Life Insurance Company } \\
\text { NYSE: (MFC) }\end{array}$ & 28,907 & 205,140 & $\mathrm{AA}^{-}$ \\
\hline
\end{tabular}

In order to answer Research Question 4, an Ordinary Least Squares (OLS) regression was calculated between contemporaneous metrics like market value of equity (MV), the dependant variable, and book value of equity (BV) and embedded value of equity (EV), the two dependent variables. Thus, the following three regressions were estimated: 


$$
\begin{aligned}
& \mathrm{MV}_{\mathrm{t}}=\mathrm{a}+\mathrm{b}_{1} \mathrm{BV}_{\mathrm{t}} \\
& \mathrm{MV}_{\mathrm{t}}=\mathrm{a}+\mathrm{b}_{2} \mathrm{EV}_{\mathrm{t}} \\
& \mathrm{MV}_{\mathrm{t}}=\mathrm{a}+\mathrm{b}_{1} \mathrm{BV}_{\mathrm{t}}+\mathrm{b}_{2} \mathrm{EV}_{\mathrm{t}}
\end{aligned}
$$

Furthermore, in order to answer Research Question 5, an OLS regression was estimated between "ex post", three-month $\left(\mathrm{MV}_{\mathrm{t}+0,25}\right)$ and one-year ahead $\left(\mathrm{MV}_{\mathrm{t}+1}\right)$, subsequent market value of equity (MV), and "ex ante" metrics like book value of equity (BV) and embedded value of equity (EV). Thus, the following six additional regressions were estimated:

$$
\begin{aligned}
& \mathrm{MV}_{\mathrm{t}+1}=\mathrm{a}+\mathrm{b}_{1} \mathrm{BV}_{\mathrm{t}} \\
& \mathrm{MV}_{\mathrm{t}+1}=\mathrm{a}+\mathrm{b}_{2} \mathrm{EV}_{\mathrm{t}} \\
& \mathrm{MV}_{\mathrm{t}+1}=\mathrm{a}+\mathrm{b}_{1} \mathrm{BV}_{\mathrm{t}}+\mathrm{b}_{2} \mathrm{EV}_{\mathrm{t}} \\
& \mathrm{MV}_{\mathrm{t}+0,25}=\mathrm{a}+\mathrm{b}_{1} \mathrm{BV}_{\mathrm{t}} \\
& \mathrm{MV}_{\mathrm{t}+0,25}=\mathrm{a}+\mathrm{b}_{2} \mathrm{EV}_{\mathrm{t}} \\
& \mathrm{MV}_{\mathrm{t}+0,25}=\mathrm{a}+\mathrm{b}_{1} \mathrm{BV}_{\mathrm{t}}+\mathrm{b}_{2} \mathrm{EV}_{\mathrm{t}}
\end{aligned}
$$

\section{THE EMPIRICAL RESULTS}

The purpose of this section is to present and more closely examine the empirical results on the informational content and the usefulness of Canadian life insurance companies' embedded value (EV) public financial disclosures. The results of the analysis will be presented in five parts each of which addressing one of the five previously formulated research questions.

\subsection{The extent of embedded value public financial disclosures across the four Canadian life insurers}

This study very closely examined the extent of embedded value public financial disclosure across the four publicly listed Canadian life insurers. This in-depth content analysis revealed that three out of four Canadian life insurers have made regular EV public financial disclosure since year-end 2000. In addition, all three companies also provide a detailed discussion and analysis of EV as can be seen for MFC in Table 1. It came as a surprise that GreatWest Lifeco, Canada's second largest life insurer by total assets, has not provided EV public financial disclosure over the 2000-2009 time period. In addition, Great-West did not indicate that it computed and made internal use of the EV metric.

\subsection{The frequency of embedded value public financial disclosure across the four Canadian life insurers}

This study also examined the frequency of embedded value public financial disclosure across the four publicly listed Canadian life insurers. This form of analysis revealed that the three companies that disclosed EV metrics only did so annually. Both Industrial Alliance Group and Manufacturers Life Insurance Company made annual EV disclosures in their Annual Report. The third company, Sun Life Assurance Company of Canada also makes annual EV financial disclosures; but it does so in its first quarter financial report.

The extent and frequency of Canadian life insurers EV public financial disclosures directly determined the number of observations available to carry out the statistical analysis described in sections 4.4 and 4.5. Three firms that disclosed annual EV metrics for ten years (2000-2009) thus provided only thirty (30) separate EV data points.

\subsection{The extent of embedded value public financial disclosure across Canadian life insurers' credit rating}

This study examined if a Canadian life insurer's credit rating could influence the extent of its EV public financial disclosure. In depth content analysis did not reveal any significant difference in the extent of EV disclosure across the individual credit rating attributed by Standard \& Poor's to Canadian life insurers' subordinated debt issues: 
- A : to Industrial Alliance Group; unchanged from year-end 2008

- $\quad$ A+ : to Sun Life Assurance; lowered from AA- at year-end 2008

- $\quad$ AA- : to The Manufacturers Life Insurance Company; lowered from AA at year-end 2008

Moreover, for the two life insurers with the same AA-credit rating; Great-West Lifeco did not disclose its EV metrics while MFC did so continuously from 2000 to 2009.

\subsection{The analysis of the relationship between contemporaneous metrics like BV, EV and MV of equity}

In order to carry out the analysis of the relationship between contemporaneous metrics like BV, EV and MV of equity, we combined the small number of available annual observations of the three Canadian life insurers into one sector sample. Because of the preliminary nature of this study, we also used for all three companies their total BV, EV and MV of equity instead of the per common share values of BV, EV and MV. Given these limits, the OLS regression results for equations (1), (2) and (3) are presented in Table 3 for the 2000-2008 study period; and also for 2000 to 2007 to abstract from the 2008 stock market turmoil.

Before examining the results presented in Table 3 on contemporaneous BV, EV and MV metrics, we again examine the contemporaneous time pattern for IAG's, MFC's and SLF's value metrics shown in Graph 1. Notice first how BV was usually lower than both EV and MV from 2000 to 2009. Second, EV was usually lower or equal to MV from 2000 to 2007. Third, during the tumultuous 2007-2009 stock market episode, MV fell below EV, but still remained higher than BV for IAG and MFC, or at least equal to BV for SLF.

Returning back to BV, EV and MV regression results shown in Table 3, we see that the contemporaneous MV metrics for all insurers were very closely related in a statistical sense to their EV metrics during the 2000-20007 time horizon. We can also observe in equations $(1)^{1}$ and $(3)^{1}$ that the relationship between MV metrics was not as significant for BV metrics as it was for EV metrics from 2000 to 2007. However, if the study period is extended to 2008, it appears that MV metrics are more closely related to BV metrics, equations (1) and (3), and naturally much less related to EV metrics as shown in equations (2) and (3).

Table 3

$\mathrm{BV}, \mathrm{EV}$ and $\mathrm{MV}$ of

Total Equity Regression Results Using Contemporaneous Metrics

\begin{tabular}{|c|c|c|c|c|c|c|c|c|c|c|c|}
\hline \multicolumn{12}{|c|}{ 2000-2008 Study Period } \\
\hline & & & & & & \multirow[b]{2}{*}{$\mathrm{BV}_{\mathrm{t}}$} & & & & $\mathbf{F}$ & $\mathbf{A d j}-\mathbf{R}^{2}$ \\
\hline (1) & $\mathrm{MV}_{\mathrm{t}}$ & $=$ & $\propto$ & + & $\begin{array}{l}\hat{B_{1}} \\
1.924 \\
t=11.421 \\
\text { p.v. }=(0.000)\end{array}$ & & & & & $\begin{array}{l}130.450 \\
\text { p.v. }=(0.000)\end{array}$ & 0.833 \\
\hline (2) & $\mathrm{MV}_{\mathrm{t}}$ & $=$ & $\propto$ & + & $\begin{array}{l}\hat{\mathrm{B}}_{2} \\
1.385 \\
\mathrm{t}=9.335 \\
\text { p.v. }=(0.000)\end{array}$ & \multicolumn{4}{|l|}{$\mathrm{EV}_{\mathrm{t}}$} & $\begin{array}{l}87.141 \\
\text { p.v. }=(0.000)\end{array}$ & 0.775 \\
\hline (3) & $\mathrm{MV}_{\mathrm{t}}$ & $=$ & $\propto$ & + & $\begin{array}{l}\hat{B_{1}} \\
2.040 \\
t=3.701 \\
\text { p.v. }=(0.001)\end{array}$ & $\mathrm{BV}_{\mathrm{t}}$ & + & $\begin{array}{l}\hat{\mathrm{B} 2} \\
-0.058 \\
-0.142 \\
(0.888) \\
\end{array}$ & $\mathrm{EV}_{\mathrm{t}}$ & $\begin{array}{l}73.469 \\
\text { p.v. }=(0.000)\end{array}$ & 0.853 \\
\hline
\end{tabular}


Table 3

$\mathrm{BV}, \mathrm{EV}$ and MV of

Total Equity Regression Results Using Contemporaneous Metrics (continued)

\begin{tabular}{|c|c|c|c|c|c|c|c|c|c|c|c|}
\hline \multicolumn{12}{|c|}{ 2000-2007 Time Horizon } \\
\hline$(1)^{1}$ & $\mathrm{MV}_{\mathrm{t}}$ & $=$ & $\propto$ & + & $\begin{array}{l}\hat{B}_{1} \\
2.163 \\
t=15.074 \\
\text { p.v. }=(0.000)\end{array}$ & $\mathrm{BV}_{\mathrm{t}}$ & & & & $\begin{array}{l}227.211 \\
\text { p.v. }=(0.000)\end{array}$ & 0.908 \\
\hline$(2)^{1}$ & $\mathrm{MV}_{\mathrm{t}}$ & $=$ & $\propto$ & + & $\begin{array}{l}\hat{\mathrm{B}}_{2} \\
1.839 \\
\mathrm{t}=24.113 \\
\text { p.v. }=(0.000)\end{array}$ & $\mathrm{EV}_{\mathrm{t}}$ & & & & $\begin{array}{l}581.45 \\
\text { p.v. }=(0.000)\end{array}$ & 0.962 \\
\hline$(3)^{1}$ & $\mathrm{MV}_{\mathrm{t}}$ & $=$ & $\propto$ & + & $\begin{array}{l}\hat{B}_{1} \\
0.178 \\
t=0.477 \\
\text { p.v. }=(0.638)\end{array}$ & $\mathrm{BV}_{\mathrm{t}}$ & + & $\begin{array}{l}\hat{\mathrm{B} 2} \\
1.697 \\
5.514 \\
(0.000) \\
\end{array}$ & . $\mathrm{EV}_{\mathrm{t}}$ & $\begin{array}{l}280.634 \\
\text { p.v. }=(0.000)\end{array}$ & 0.960 \\
\hline
\end{tabular}

\subsection{The analysis of the relationship between contemporaneous metrics like BV, EV and "ex post" MV of equity}

The BV, EV and MV of equity regression results are extended by using one-year ahead values for MV accompanied by contemporaneous values for BV and EV; the results of this form of statistical analysis are shown in Table 4. It can be observed that "ex post" values of $\mathrm{MV}_{\mathrm{t}+1}$ were more closely related to "ex ante" values of EV than "ex ante" values of BV for Canadian insurers from 2000 to 2008 inclusively. Notice here that $\mathrm{MV}_{\mathrm{t}+1}$ values for 2009 were not yet available at the time of writing the Préfontaine et al. (2009) paper. Thus, it would appear that contemporaneous EV financial disclosures help explain MV of equity metrics as far as one-year ahead.

Table 4

$\mathrm{BV}, \mathrm{EV}$ and $\mathrm{MV}$ of

Total Equity Regression Results Using One-Year Ahead Values for MV

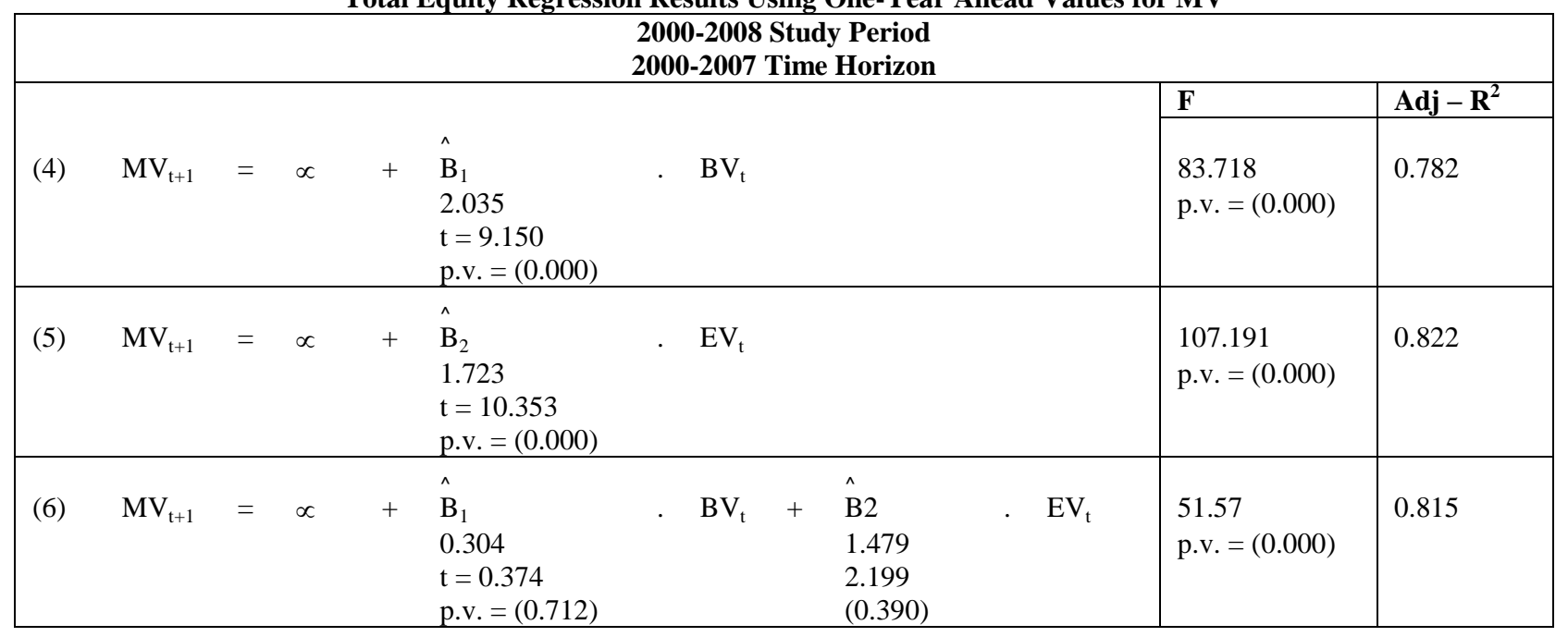

In addition, the BV, EV and MV of equity regression results were again extended by using three-month ahead values for $\mathrm{MV}_{\mathrm{t}+0,25}$ accompanied by contemporaneous values for $\mathrm{BV}$ and $\mathrm{EV}$; the results of this form of 
statistical analysis are presented in Table 5. Notice that three-month ahead $\mathrm{MV}_{\mathrm{t}+0,25}$ of equity metrics for Canadian life insurers were more closely related to EV than BV metrics during the 2000-2007 time period as shown in equations $\left(7^{1}\right),\left(8^{1}\right)$ and $\left(9^{1}\right)$. However, if the analysis includes the more tumultuous 2008 stock market episode the opposite holds true. That is, the three-month ahead $\mathrm{MV}_{\mathrm{t}+0,25}$ of equity metrics were more closely related to $\mathrm{BV}$ than EV metrics during the 2000-2008 time horizon.

Table 5

BV, EV and MV of Total Equity Regression Results Using One-Quarter Ahead Values for MV

\begin{tabular}{|c|c|c|c|c|c|c|c|c|c|c|c|}
\hline \multicolumn{12}{|c|}{ 2000-2008 Study Period } \\
\hline \multirow[b]{2}{*}{ (7) } & \multirow[b]{2}{*}{$\mathrm{MV}_{\mathrm{t}+0.25}$} & \multirow[b]{2}{*}{$=$} & \multirow[b]{2}{*}{$\propto$} & \multirow[b]{2}{*}{+} & & \multirow[b]{2}{*}{. $\quad \mathrm{BV}_{\mathrm{t}}$} & & & & $\mathbf{F}$ & $\mathbf{A d j}-\mathbf{R}^{2}$ \\
\hline & & & & & $\begin{array}{l}\hat{B_{1}} \\
1.861 \\
t=9.299 \\
\text { p.v. }=(0.000)\end{array}$ & & & & & $\begin{array}{l}86.47 \\
\text { p.v. }=(0.000)\end{array}$ & 0.767 \\
\hline (8) & $\mathrm{MV}_{\mathrm{t}+0.25}$ & $=$ & $\propto$ & + & $\begin{array}{l}\hat{B}_{2} \\
1.306 \\
t=7.325 \\
\text { p.v. }=(0.000)\end{array}$ & \multicolumn{3}{|l|}{. $\quad \mathrm{EV}_{\mathrm{t}}$} & & $\begin{array}{l}53.658 \\
\text { p.v. }=(0.000)\end{array}$ & 0.678 \\
\hline (9) & $\mathrm{MV}_{\mathrm{t}+0.25}$ & $=$ & $\propto$ & + & $\begin{array}{l}\hat{B}_{1} \\
2.575 \\
t=4.015 \\
\text { p.v. }=(0.001)\end{array}$ & . $\mathrm{BV}_{\mathrm{t}}$ & . & $\begin{array}{l}\hat{\text { B2 }} \\
-0.516 \\
-1.087 \\
(0.288)\end{array}$ & $\mathrm{EV}_{\mathrm{t}}$ & $\begin{array}{l}51.793 \\
\text { p.v. }=(0.000)\end{array}$ & 0.803 \\
\hline \multicolumn{12}{|c|}{ 2000-2007 Time Horizon } \\
\hline$(7)^{1}$ & $\mathrm{MV}_{\mathrm{t}+0.25}$ & $=$ & $\propto$ & + & $\begin{array}{l}\hat{B}_{1} \\
2.206 \\
t=16.041 \\
\text { p.v. }=(0.000)\end{array}$ & . $\quad \mathrm{BV}_{\mathrm{t}}$ & & & & $\begin{array}{l}257.299 \\
\text { p.v. }=(0.000)\end{array}$ & 0.918 \\
\hline$(8)^{1}$ & $\mathrm{MV}_{\mathrm{t}+0.25}$ & $=$ & $\propto$ & + & $\begin{array}{l}\hat{B}_{2} \\
1.869 \\
t=25.578 \\
\text { p.v. }=(0.000)\end{array}$ & . $\mathrm{EV}_{\mathrm{t}}$ & & & & $\begin{array}{l}654.24 \\
\text { p.v. }=(0.000)\end{array}$ & 0.966 \\
\hline$(9)^{1}$ & $\mathrm{MV}_{\mathrm{t}+0.25}$ & $=$ & $\propto$ & + & $\begin{array}{l}\hat{B}_{1} \\
0.290 \\
t=0.821 \\
\text { p.v. }=(0.421)\end{array}$ & . $\mathrm{BV}_{\mathrm{t}}$ & + & $\begin{array}{l}\hat{B} 2 \\
1.638 \\
5.610 \\
(0.000)\end{array}$ & $\mathrm{EV}_{\mathrm{t}}$ & $\begin{array}{l}322.61 \\
\text { p.v. }=(0.000)\end{array}$ & 0.965 \\
\hline
\end{tabular}

In order to update the authors' previous findings (2009), Table 6 presents total equity regression results for the extended 2000-2009 study period using contemporaneous, one-quarter and one-year ahead values for MV as a function of "ex ante" values for BV and EV. First notice in Table 6 that total equity regression results indicate that F test values were highest when using contemporaneous values for MV the dependent variable, next to highest using one-quarter ahead values for MV, and lowest when using one-year ahead values for MV. Second, the results for the complete 2000-2009 study period indicate that contemporaneous values of Canadian life insurance companies' MVs were more closely associated with their BVs than their EVs; especially so from 2007 to 2009. Third, the results for the complete 2000-2009 study period also indicate that "ex post" one-quarter and one-year ahead values of Canadian life insurance companies' MVs were more closely associated with their BVs than their EVs; again, especially so from 2007 to 2009. 
Table 6

$\mathrm{BV}, \mathrm{EV}$ and MV of

Total Equity Regression Results Using Contemporaneous, One-Year and One-Quarter Ahead Values for MV

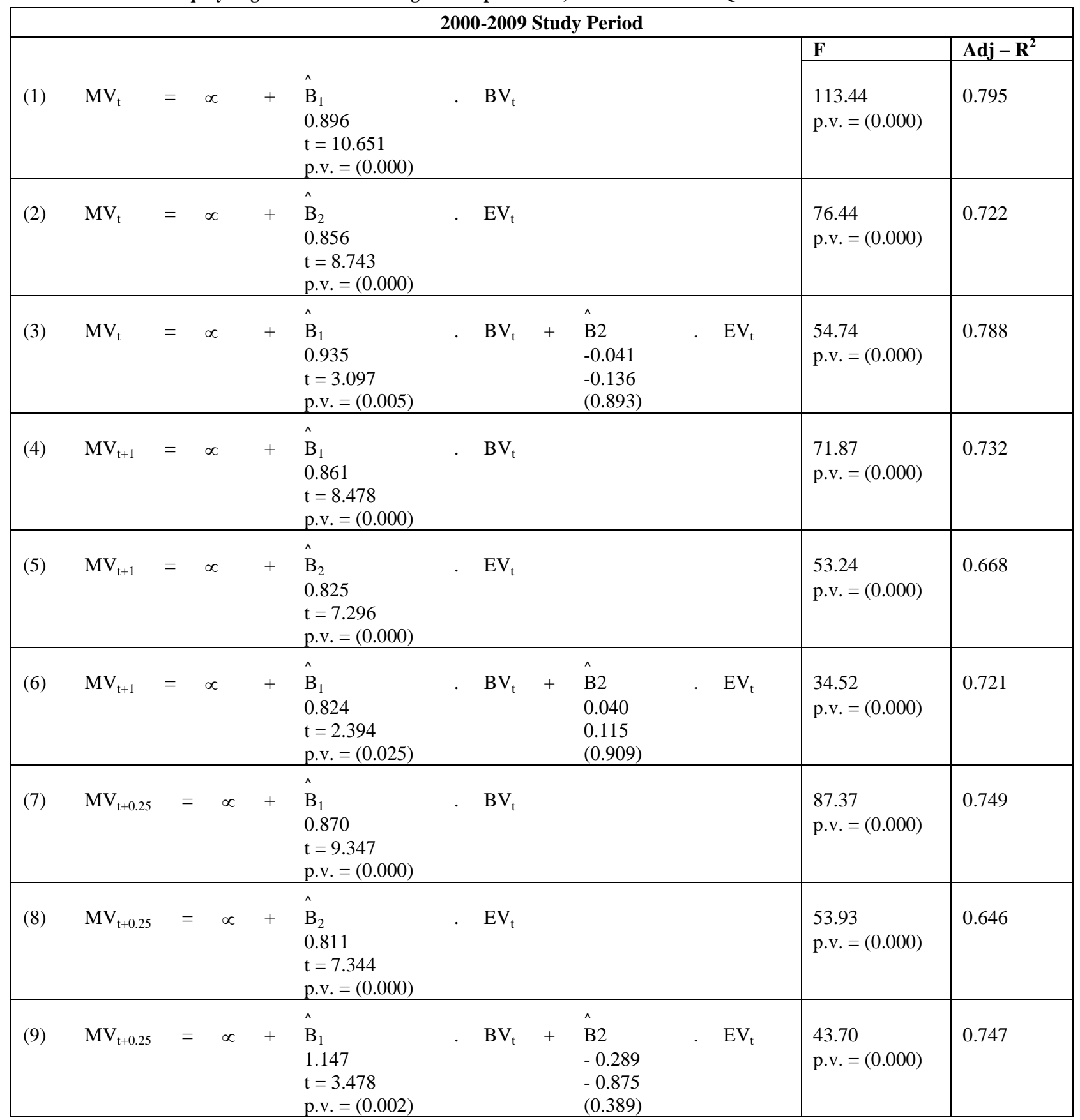

\section{DISCUSSION AND CONCLUSION}

This paper examined the informational content of voluntary embedded value (EV) financial disclosures by a sample of Canadian life insurance companies. As an answer to the first research question formulated in section 3.1 of this paper, the preliminary results indicate that three out of four large Canadian life insurers now disclose annually their EV metrics. Three of four sample firms made continuous EV disclosures from 2000 to 2009; while 
one large firm made no EV disclosures at all during that period. As an answer to the second question, content analysis indicates that Canadian life insurers do not make EV financial disclosures on a quarterly basis. This low frequency of EV disclosures thus limits the number of observations for each firm and total sample size for all disclosing firms. In addition, content analysis did not document a propensity to voluntary EV financial disclosure that was a function of a firm's long term debt credit rating.Despite a relatively small number of companies generating a relatively small number of EV financial disclosures that could be studied in this paper, it appears that the statistical results are quite interesting. In fact, the BV, EV and MV of total equity regression results using contemporaneous metrics support the preliminary conclusion that embedded value (EV) financial disclosures by Canadian life insurance companies provided relevant informational content from 2000 to 2007; but less much so if the tumultuous 2007-2010 stock market episode is included. Moreover, the BV, EV and MV of total equity regression results using one-year ahead and three-month ahead MV of equity metrics also support the preliminary conclusion that embedded value (EV) financial disclosures by Canadian life insurance companies provided relevant informational content from 2000 to 2007; but less much so if the tumultuous 2007-2010 stock market episode is included. Since the preliminary empirical evidence presented in this paper on Canadian life insurance companies' EV voluntary financial disclosures seems promising, it will be interesting to extend the analysis in the future by including a larger number of major life insurance companies drawn from various other world regions such as Asia, Europe and the United States.

\section{ACKNOWLEDGEMENTS}

Financial support from the Desjardins chair in managing sustainable development and the Research Group in Applied Finance (GREFA) is gratefully acknowledged.

Data availability: The data used in this study can be obtained from public sources.

\section{AUTHOR INFORMATION}

Dr. Préfontaine is Professor of Finance at Faculté d'Administration Université de Sherbrooke, and Desjardins Chair in managing sustainable development. His professional, teaching and research interests have focused on financial institutions management, risk management and corporate social responsibility.

Dr. Desrochers is Professor of Finance and director of the undergraduate program at Faculté d'Administration Université de Sherbrooke, and research director of the Desjardins Chair in managing sustainable development. His professional, teaching and research interests have focused on portfolio theory, risk management and socially responsible investment.

Mrs. Godbout is a fourth year DBA student at Faculté d'Administration Université de Sherbrooke, and research assistant of the Desjardins Chair in managing sustainable development. Her professional, teaching and research interests have focused on financial institutions management, integrated risk management and corporate social responsibility.

\section{REFERENCES}

1. Basel Committee on Banking Supervision, The Joint Forum, 2006. "The Management of Liquidity Risk in Financial Groups.” Bank for International Settlements (May).

2. Basel Committee on Banking Supervision.2004. "International Convergence of Capital Measurement and Capital Standards: a Revised Framework.” No. 107 (June).

3. Basel Committee on Banking Supervision, The Joint Forum, 2004. "Financial Disclosure in the Banking, Insurance and Securities Sectors: Issues and Analysis.” Bank for International Settlements (May).

4. Basel Committee on Banking Supervision. 2003b. "Public Disclosures by Banks: Results of the 2001 Disclosure Survey.” Basel Committee Publications No. 97 (May).

5. Board of Governors of the Federal Reserve System. 2000. "Improving Public Disclosure in Banking." Staff Study \# 173. 
6. Boussanni, A., Desrochers, J., Préfontaine, J. (2008). "Liquidity Risk Financial Disclosure: The Case of Large European Financial Groups.” International Business \& Economics Research Journal, Vol. 7(7), July 2008.

7. Desrochers, J. Préfontaine, J. (2008). "Principles for Sound Liquidity Risk Management and Supervision." Basel Committee on Banking Supervision, Working Group on Liquidity, Bank for International Settlements, July 2008, pp. 1-8.

8. Hirst, D.E., P.E. Hopkins, and J.M. Wahlen. 2004. "Fair Values, Income Measurement, and Bank Analysts' Risk and Valuation Judgments." The Accounting Review 79, pp.453-472.

9. Hirtle, B.J. 2003. "What Market Risk Capital Reporting Tells Us About Bank Risk." Economic Policy Review 9, FRBNY, (September), pp.37-54.

10. Horton, J. 2007. "The Value Relevance of 'Realistic Reporting': Evidence from UK Life Insurers." Accounting and Business Research, vol. 37(3), pp. 175-197.

11. Jorion, P. 2002. "How Informative Are Value-at-Risk Disclosures?” The Accounting Review 77, pp. 911931.

12. Ke, B. 2004. "Discussion of How Banks' VaR Disclosures Predict their Total and Priced Risk." Review of Accounting Studies 9 (June-September), pp. 295-299.

13. Kwan, Simon H. 2002. "Bank Security Prices and Market Discipline.” FRBSF Economic Letter 2002-37 (December 20).

14. Kwan, Simon H. 2006. "Safe and Sound Banking, 20 Years Later.” FRBSF Economic letter 2006-26 (October 6).

15. Linsmeier, T., D. Thornton, M. Venkatachalam, and M. Welker. 2002. "The effect of mandated market risk disclosure on trading volume sensitivity to interest rate, exchange rate, and commodity price movements." The Accounting Review 77 (April): 343-378.

16. Liu, C.C., Ryan, S.G., Tan, H. 2004. "How Banks' VaR Disclosures Predict their Total and Priced Risk." Review of Accounting Studies 9 (June-September), pp. 265-294.

17. Lopez, Jose A. 2004. "Supervising Interest Rate Risk Management." FRBSF Economic Letter 2004-26 (September 17).

18. Lopez, Jose A. 2003. "Disclosure as a Supervisory Tool: Pillar 3 of Basel II.” FRBSF Economic Letter 2003-22 (August 1).

19. Préfontaine, J., Desrochers, J., Kadmiri, O. 2006a. “How Informative Are Banks' Earnings-at-Risk and Economic Value of Equity-at-Risk Public Disclosures?” Insurance and Risk Management, vol. 74 (1), April, 1-19.

20. Préfontaine, J., Houde, D., Desrochers, J., Martel, D. 2006b. “The Informational Content of the VaR Measures Associated with the Trading Activities of Canadian Banks". IBER conference, Las Vegas Nevada, October 2006, Best paper award, to be published in 2007 in the Journal of Business and Economics Research.

21. Préfontaine, J., Desrochers, J., Godbout, L. 2009. “The Informational Content of Voluntary Embedded Value (EV) Financial Disclosures by Canadian Life Insurance Companies”. International Business \& Economics Research Journal, Vol. 8(12), December 2009.

22. Sierra, G. E., Yeager, T. J. 2004. "What Does The Federal Reserve's Economic Value Model Tell Us About Interest Rate Risk at U.S. Community Banks?” Review 86, FRBSL (Nov./Dec.), pp. 45-60. 
NOTES 